\title{
Effects of Bee Propolis on FBG, HbA1c, and Insulin Resistance in Healthy Volunteers
}

\section{Sağlıklı Gönüllülerde Arı Propolisinin FBG, HbA1c ve İnsülin Direnci Üzerine Etkileri}

\author{
(D) Fawaz A ALASSAF1, (D) Mahmood H M JASIM²*, (D) Mohanad ALFAHAD³, (D) Mohannad E QAZZAZ4 , (D) Mohammed N ABED22, \\ (D) Imad A-J THANOON5 \\ ${ }^{1}$ Mosul University College of Pharmacy, Department of Pharmacology and Toxicology, Mosul, Iraq \\ 2Mosul University College of Pharmacy, Department of Pharmaceutical Chemistry, Mosul, Iraq \\ 3 Mosul University College of Pharmacy, Department of Pharmaceutics, Mosul, Iraq \\ 4 Mosul University College of Pharmacy, Department of Pharmacognosy and Medicinal Plants, Mosul, Iraq \\ 5 Mosul University College of Medicine, Department of Pharmacology, Mosul, Iraq
}

\section{ABSTRACT}

Objectives: Bee propolis is a natural substance that is used in traditional medicine due to its versatile pharmacological actions. This study evaluates whether short term use of bee propolis supplementation could have an impact on glycemic control in healthy individuals.

Materials and Methods: A single daily dose of $1000 \mathrm{mg}$ of bee propolis was administered orally to a total of 34 healthy individuals for 60 days. Body weight, body mass index (BMI), fasting blood glucose (FBG), glycosylated hemoglobin (HbA1c), and insulin resistance were measured in all participants before and after the use of bee propolis.

Results: The results of this study showed that bee propolis was associated with a significant increase in body weight and BMI of healthy volunteers. Bee propolis supplementation decreased FBG and HbA1c, but did not affect insulin resistance.

Conclusion: Based on these results, bee propolis supplementation has a potential effect on glycemic control in healthy individuals and this should be considered when using this supplement in medical conditions.

Key words: Bee propolis, insulin resistance, healthy volunteers, fasting blood glucose, natural products

Öz

Amaç: Arı propolisi, çok yönlü farmakolojik etkileri nedeniyle geleneksel tıpta kullanılan doğal bir maddedir. Bu çalışma, kısa süreli arı propolis takviyesi kullanımının sağlıklı bireylerde glisemik kontrol üzerinde bir etkisi olup olmadığını değerlendirmektedir.

Gereç ve Yöntemler: Toplam 34 sağlıklı bireye 60 gün boyunca günde tek doz 1000 mg arı propolisi oral yoldan verilmiștir. Arı propolisinin kullanımı öncesi ve sonrasında tüm katılımcılarda vücut ağırlığı, vücut kitle indeksi (VKi), açlık kan şekeri (AKŞ), glikozile hemoglobin (HbA1c) ve insülin direnci ölçülmüștür.

Bulgular: Bu çalıșmanın sonuçları, arı propolisinin sağlıklı gönüllülerin vücut ağırlığında ve VKi'sinde belirgin bir artış ile ilişkili olduğunu göstermiştir. Arı propolisi takviyesi AKŞ ve HbA1c'yi azaltmıș, ancak insülin direncini etkilememiștir.

Sonuç: Bu sonuçlara dayanarak, arı propolis takviyesinin sağlıklı bireylerde glisemik kontrol üzerinde potansiyel bir etkisi olduğu söylenebilir ve bu takviye tıbbi durumlarda kullanılırken bu dikkate alınmalıdır.

Anahtar kelimeler: Arı propolisi, insülin direnci, sağlıklı gönüllüler, açlık kan şekeri, doğal ürünler

\footnotetext{
*Correspondence: mh.jasim@uomosul.edu.iq, Phone: +009647704503960, ORCID-ID: orcid.org/0000-0002-8198-8246

Received: 16.07.2020, Accepted: 08.09.2020

๑Turk J Pharm Sci, Published by Galenos Publishing House.
} 


\section{INTRODUCTION}

Natural products are promising candidates for the development of new medications. Bee propolis is one such product. It is a resinous substance that is synthesized by bees from bees' wax and saliva combined with exudates from plants. Bees make use of their synthesized propolis for the building and maintenance of their hives. Anciently, bee propolis has been used in traditional medicine for healing purposes, such as wound and ulcer healing. ${ }^{2}$ The constituents of raw propolis are resins (50\%), waxes (30\%), essential oils (10\%), pollen (5\%), and various other organic compounds (5\%). Chemically, bee propolis is composed of more than 300 natural ingredients, including coumarins, phenolic compounds and esters, flavonoids, steroids, aldehydes, amino acids sesquiterpenes, and stilbene terpenes., 3

Bee propolis has become a healthy supplement, with several studies demonstrating an association of bee propolis consumption with remarkable biological and pharmacological effects. Bee propolis has demonstrated antimicrobial, ${ }^{5}$ antiinflammatory, ${ }^{6}$ antioxidant, ${ }^{7}$ antiviral, ${ }^{8}$ anticancer, ${ }^{9}$ immunoregulatory actions, ${ }^{10}$ and protective effects on the liver, pancreas, heart, and brain. ${ }^{11,12}$ It has been documented that the main constituents of propolis responsible for its therapeutic effects include flavonoids, phenols, and aromatic compounds. ${ }^{13}$ Flavonoids and phenolic compounds in bee propolis exhibit a potent antioxidant activity against oxygen radicals and protect biological membranes from lipid peroxidation. ${ }^{14}$ Oxidative stress is involved, among others, in $\beta$-cell dysfunction, insulin resistance, and impaired glucose tolerance, and it poses a higher risk for the development of type 2 diabetes. ${ }^{15,16}$ In this context, bee propolis can be considered for glycemic control because of its high antioxidant properties. More recently, studies have demonstrated that bee propolis results in a significant decrease in the blood glucose levels, serum glycosylated hemoglobin ( $\mathrm{HbA1c}$ ) levels, and serum insulin levels, with improvement of insulin resistance in patients with type 2 diabetes. ${ }^{17,18}$

The acclaimed beneficial effect of bee propolis in diabetes was the main motivation for conducting this study to ascertain the safety of this dietary supplement in non-diabetic individuals. Bee propolis is used by many healthy, or at least, non-diabetic people as a dietary supplement. Since it has shown some beneficial effects in people with diabetes, this study aimed to investigate the effects of bee propolis, if any, on fasting blood glucose (FBG), HbA1c, and insulin sensitivity in healthy subjects.

\section{MATERIALS AND METHODS}

\section{Study design and methodology}

This study was conducted in compliance with the research ethics standards of the institutional and national ethical committees. This study is also ethically compliant with the 1975 Helsinki declaration and its following revisions. Approval for conducting the study was obtained from the scientific and ethical committees at the College of Pharmacy, University of Mosul and Nineveh Health Directorate, respectively. The Scientific and
Ethical Research Committee within Nineveh Health Directorate approved the study, with its session numbered 180 on January 02, 2019.

The study was conducted on apparently healthy volunteers of both genders who were aged between 25 and 40 years and had a body mass index (BMI) that ranged from $18.5 \mathrm{~kg} \cdot \mathrm{m}^{-2}$ to $25 \mathrm{~kg} \cdot \mathrm{m}^{-2}$ (Table 1). Subjects with BMl $\left\langle 18.5 \mathrm{~kg} / \mathrm{m}^{2}\right.$ and $>25$

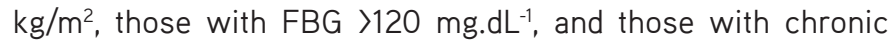
diseases or on dietary supplements were excluded from the study. Subjects were selected randomly from different levels of employees at the College of Pharmacy, University of Mosul. Volunteers were recruited for the study from January to April 2019. A convenient sample of 40 subjects was initially taken; however, 6 people were excluded from the study due to the lack of compliance. All participants involved in this study were well-informed of the approved study protocol and were asked to sign an informed consent form before taking part in the study. The participants received 60 capsules of $1000 \mathrm{mg}$ of bee propolis (Woods Supplements, United Kingdom), which they were instructed to take for 2 months as a single daily dose. Before and after treatment with bee propolis, $5 \mathrm{~mL}$ venous blood samples were collected from each individual following a minimum of 8 hours fasting period between 9 am and 11 am. HbA1c test was performed using DCA Vantage Analyzer (Siemens ${ }^{\circledR}$ ) and completed within 2 hours of blood collection. ${ }^{19}$ For other tests, blood samples were centrifuged for 10 minutes at room temperature and serums were collected and stored at $-20^{\circ} \mathrm{C}$ until the day of assay. FBG was measured using the hexokinase method with an automated analyzer (Cobas c111, Roche) following the manufacturer's instructions. ${ }^{20,21}$ Serum insulin was measured using electro-chemiluminescence technology for immunoassay analysis (Cobas e 411 Roche).22 FBG and serum insulin readings were used to calculate homeostasis model assessment-insulin resistance (HOMA-IR) according to the following equation:

HOMA-IR=Fasting glucose $(\mathrm{mg} / \mathrm{dL}) \times$ fasting insulin $\left(\mu \mathrm{U} \mathrm{mL} \mathrm{L}^{-1}\right) / 405 .{ }^{23}$

\section{Statistical analysis}

Data obtained from this study were normally distributed as all sample sets passed the D'Agostino \& Pearson normality test. All results were presented as mean \pm standard deviation. Student's paired t-test for single data comparison was performed using

Table 1. General characteristics of healthy volunteers

\begin{tabular}{ll} 
Parameters & Values \\
\hline Age, (mean) years & 36.88 \\
\hline Male, $\mathrm{n}$ & 23 \\
\hline Female, $\mathrm{n}$ & 11 \\
\hline Weight, (mean) kg & 73.4 \\
\hline BMl, (mean) kg/m² & 24.2 \\
\hline Smoker, $\mathrm{n}$ & 7
\end{tabular}

BMI: Body mass index 
GraphPad Prism 8.0 software. Differences between means were considered significant at $p<0.05$.

\section{RESULTS}

Thirty-four healthy individuals aged 25-45 years were chosen according to the inclusion criteria of the current study. The mean age of participants was 36.88 years. Females represented $32.4 \%$ of the participants, whereas males represented $67.6 \%$ (Table 1). The effect of bee propolis on body weight and BMI after 60 days is shown in Figure 1. At the end of the study, the mean weight and mean BMl increased significantly from $73.4 \pm 7.2$ to $74.8 \pm 7.5 \mathrm{~kg}$ and from $24.2 \pm 1.2$ to $24.7 \pm 1.5 \mathrm{~kg} \mathrm{~m}^{-2}$ ( $p<0.01)$, respectively.

FBG, HbA1c, and serum insulin levels were measured at the onset of the study and on day 60 after the administration of bee propolis, as shown in Figure 2. There was significant reduction in the mean FBG level from $101.9 \pm 9.1$ to $92.69 \pm 13 \mathrm{mg} \mathrm{dL}^{-1}$ ( $p<0.01$ ) and in the mean $\mathrm{HbA1c}$ level from $5.1 \pm 0.3$ to $4.8 \pm 0.4$ ( $p<0.01$ ) after consuming bee propolis for 60 days. Insulin levels (which reduced from $7.3 \pm 1.7$ to $7.2 \pm 2, p=0.1$ ) and HOMA-IR (which reduced from $1.7 \pm 06$ to $1.66 \pm 0.6, p=0.1$ ) were not significantly affected by the administration of bee propolis.

\section{DISCUSSION}

Globally, people consume dietary supplements to boost their health. The past 20 years have seen a widespread use of dietary supplements as these products provide several health benefits. Bee propolis is one of these natural dietary supplements that has several health-promoting effects, thereby making it gain high popularity recently. However, more studies are required to substantiate the contribution of bee propolis to human health.

In this study, it was observed that the daily administration of $1000 \mathrm{mg}$ of bee propolis for 60 days resulted in an increase in body weight and BMI, with a reduction in FBG and $\mathrm{HbA1c}$ levels in healthy volunteers. This study did not find any significant
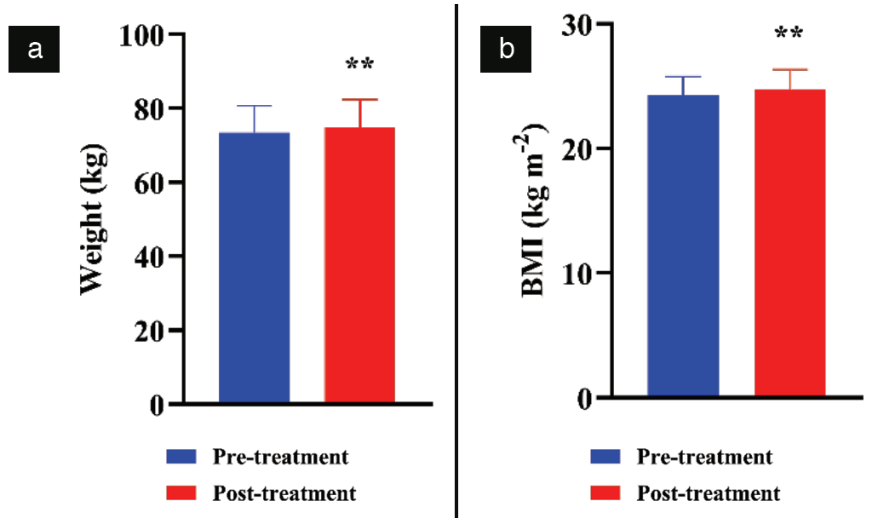

Figure 1. Effect of bee propolis treatment on body weight (a) and BMI (b). Bee propolis was administered orally as 1 gram per day for 60 days. The measurements were done before (pre-treatment) and after the bee propolis treatment (post-treatment). Data were presented as mean \pm standard deviation

${ }^{* *} \mathrm{P}<0.01$ indicates a difference with statistical significance (Student's paired t-test) between pre- and post-treatments, BMI: Body mass index change in human insulin level levels. Similarly, no significant effect of bee propolis on insulin resistance was observed.

This study has not validated the previous research on the effect of bee propolis on weight and BMI. Zakerkish et al. ${ }^{17}$ and Samadi et al. ${ }^{18}$ did not report any significant changes in body weight following the administration of bee propolis for 3 months in their clinical studies. Moreover, other studies demonstrated a weight loss in animals as a result of the laxative effect and prevention of intestinal fat absorption by bee propolis. ${ }^{24,25}$ In the present study, the administration of bee propolis for 2 months was associated with a significant increase in body weight and $\mathrm{BMI}$ of the participants. One suggested mechanism is probably the propolis-stimulated hepatic glycolysis and glucose uptake by peripheral tissues via the increase of insulin-sensitive glucose transporter, which also has a beneficial effect on glycemic control. ${ }^{26-28}$ In this study, it was observed that appetite was enhanced among the volunteers and this could be another possible mechanism for an increase in body weight and BMI.

The present study also demonstrated a favorable effect of bee propolis on FBG and HbA1c levels in healthy subjects; however, none of the subjects experienced hypoglycemic symptoms. This

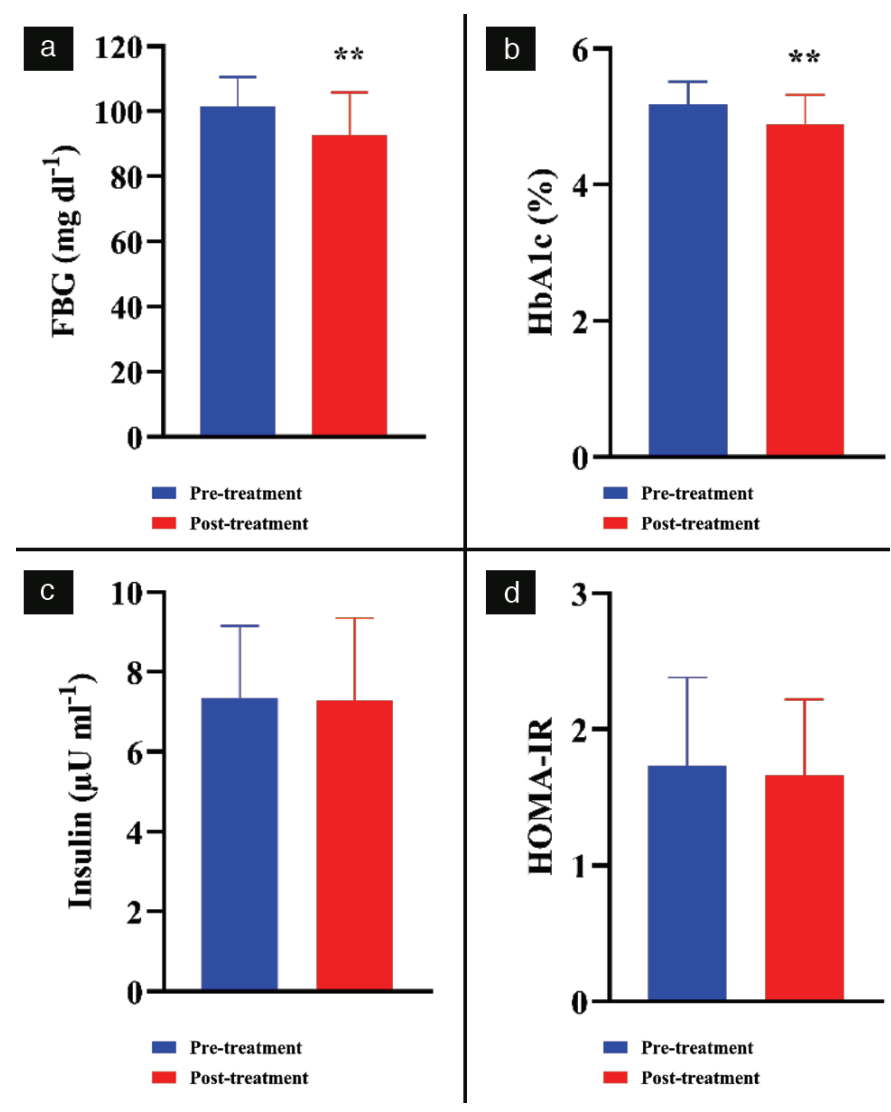

Figure 2. Effect of bee propolis treatment on FBG (a), HBA1c (b), serum insulin (c), and HOMA-IR (d). Bee propolis was administered orally as 1 gram per day for 60 days. Measurements were done before (pre-treatment) and after the bee propolis treatment (post-treatment). Data were presented as mean \pm standard deviation

${ }^{* *} \mathrm{P}<0.01$ indicates a difference with statistical significance (Student's paired t-test) between pre- and post-treatments, FBG: Fasting blood glucose, HBA1c: Glycosylated hemoglobin, HOMA-IR: Homeostasis model assessment-insulin resistance 
is consistent with some studies that showed a reduction in FBG and $\mathrm{HbA1c}$ levels in type 2 diabetic patients. . $^{17,1829,30}$ As a possible mechanism, a decrease in intestinal glucose absorption due to reduction in carbohydrate digestion, which is attributed to the inhibition of intestinal $\alpha$-glucosidase and sucrase by aqueous ethanolic propolis extract, was proposed. ${ }^{26,31}$ Moreover, propolis extracts stimulate the $\beta$-cells of the islets of Langerhans, causing an enhancement of insulin secretion. ${ }^{32}$

Insulin is a pancreas-secreted hormone that is responsible for glucose utilization by body cells, consequently resulting in a decrease in blood glucose levels. ${ }^{33}$ In this research, bee propolis was found to lower blood glucose levels. To ascertain whether this outcome was associated with the production of insulin, insulin levels and insulin resistance were determined and the results indicated that propolis had no effect on these parameters in healthy subjects. However, some studies demonstrated that prescribed propolis supplementation can significantly decrease the level of serum insulin and insulin resistance indices in patients with type 2 diabetes mellitus. 17,34-36 Zakerkish et al. ${ }^{17}$ demonstrated that insulin levels and insulin resistance in patients with type 2 diabetes receiving propolis supplementations for 3 months were lower than those in healthy controls.

Furthermore, the present study did not show any genderrelated difference in the results (data not shown) and this is in agreement with Jasprica et al. ${ }^{37}$ who found that the levels of glucose, iron binding proteins, and uric acid, in addition to lipid profile parameters, were not different between men and women. However, in their study, there was a significant genderbased variation in the oxidative status and this was attributed to estrogen, which is known to exhibit a potent antioxidant effect in women. ${ }^{37}$

\section{Study limitations}

The sample size and the short time of data collection are the main limitations of this study, which suggest the need for future studies with extended period of propolis administration (more than 2 months) and larger sample size. However, based on our results, we recommend that the BMI and waist circumference of individuals receiving bee propolis should be monitored regularly. The bee propolis used in this study was supplied as a concentrate of whole propolis product prepared in the form of capsules and not as an extract of a single or few active compounds. Our rationale for this choice of formulation was that propolis effect may be obtained as a result of the synergistic action of its numerous components rather than one active compound. Nevertheless, future studies are still needed to identify the exact quantitative composition of the active compounds, and knowledge of the concentrations of the active components might further help to explain the obtained results.

\section{CONCLUSION}

This study revealed that a daily intake of $1000 \mathrm{mg}$ of bee propolis supplements for 2 months is associated with an increase in body weight and $\mathrm{BMI}$ as well as a decrease in FBG and $\mathrm{HbA1c}$ levels in healthy individuals. Moreover, the possible long- term effects of increased weight or BMI could provoke insulin resistance, despite the fact that propolis enhanced glucose tolerance by increasing glucose uptake. Increased weight gain may be a result of this increased glucose uptake, and therefore, a vicious circle of events may be propagated, especially with enhanced appetite.

\section{ACKNOWLEDGEMENTS}

The authors are grateful to Dr. Ahmed Mohammed Ibrahim and Ms Merbad Momtaz at the University of Mosul, College of Pharmacy for their assistance in collecting blood samples from the volunteers. The contribution of the University of Mosul and the College of Pharmacy to the successful completion of this work is deeply appreciated by the authors.

Conflict of interest: No conflict of interest was declared by the authors. The authors are solely responsible for the content and writing of this paper.

\section{REFERENCES}

1. Búfalo MC, Candeias JM, Sforcin JM. In vitro cytotoxic effect of Brazilian green propolis on human laryngeal epidermoid carcinoma (HEp-2) cells. Evid Based Complement Alternat Med. 2009;6:483-487.

2. Ghisalberti EL. Propolis: A review. Bee World. 1979;60:59-84.

3. Burdock GA. Review of the biological properties and toxicity of bee propolis (propolis). Food Chem Toxicol. 1998;36:347-363.

4. Pietta PG, Gardana C, Pietta AM. Analytical methods for quality control of propolis. Fitoterapia. 2002;73(Suppl 1):S7-S20.

5. Verma MK, Pandey RK, Khanna R, Agarwal J. The antimicrobial effectiveness of $25 \%$ propolis extract in root canal irrigation of primary teeth. J Indian Soc Pedod Prev Dent. 2014;32:120-124.

6. Bueno-Silva B, Rosalen PL, Alencar SM, Mayer MPA. Anti-inflammatory mechanisms of neovestitol from Brazilian red propolis in LPS-activated macrophages. J Funct Foods. 2017;36:440-447.

7. Zhang J, Shen X, Wang K, Cao X, Zhang C, Zheng H, Hu F. Antioxidant activities and molecular mechanisms of the ethanol extracts of Baccharis propolis and Eucalyptus propolis in RAW64.7 cells. Pharm Biol. 2016;54:2220-2235.

8. Sartori G, Pesarico AP, Pinton S, Dobrachinski F, Roman SS, Pauletto F, Rodrigues LC Jr, Prigol M. Protective effect of brown Brazilian propolis against acute vaginal lesions caused by herpes simplex virus type 2 in mice: involvement of antioxidant and anti-inflammatory mechanisms. Cell Biochem Funct. 2012;30:1-10.

9. Demir S, Aliyazicioglu Y, Turan I, Misir S, Mentese A, Yaman SO, Akbulut K, Kilinc K, Deger O. Antiproliferative and proapoptotic activity of Turkish propolis on human lung cancer cell line. Nutr Cancer. 2016;68:165-172.

10. Orsatti CL, Missima F, Pagliarone AC, Bachiega TF, Búfalo MC, Araújo JP Jr, Sforcin JM. Propolis immunomodulatory action in vivo on Tolllike receptors 2 and 4 expression and on pro-inflammatory cytokines production in mice. Phytother Res. 2010;24:1141-1146.

11. Tolba MF, Azab SS, Khalifa AE, Abdel-Rahman SZ, Abdel-Naim AB. Caffeic acid phenethyl ester, a promising component of propolis with a plethora of biological activities: a review on its anti-inflammatory, neuroprotective, hepatoprotective, and cardioprotective effects. IUBMB Life. 2013;65:699-709. 
12. Babatunde IR, Abdulbasit A, Oladayo MI, Olasile OI, Olamide FR, Gbolahan BW. Hepatoprotective and pancreatoprotective properties of the ethanolic extract of nigerian propolis. J Intercult Ethnopharmacol. 2015;4:102-108.

13. Toreti VC, Sato HH, Pastore GM, Park YK. Recent progress of propolis for its biological and chemical compositions and its botanical origin. Evid Based Complement Alternat Med. 2013;2013:697390.

14. Kolankaya D, Selmanoğlu G, Sorkun K, Salih B. Protective effects of Turkish propolis on alcohol-induced serum lipid changes and liver injury in male rats. Food Chem. 2002;78:213-217.

15. Szulińska M, Stępień M, Kręgielska-Narożna M, Suliburska J, Skrypnik D, Bąk-Sosnowska M, Kujawska-Łuczak M, Grzymisławska M, Bogdański $P$. Effects of green tea supplementation on inflammation markers, antioxidant status and blood pressure in $\mathrm{NaCl}$-induced hypertensive rat model. Food Nutr Res. 2017;61:1295525.

16. Sun L, Dutta RK, Xie P, Kanwar YS. Myo-Inositol Oxygenase Overexpression Accentuates Generation of Reactive Oxygen Species and Exacerbates Cellular Injury following High Glucose Ambience: a new mechanism relevant to the pathogenesis of diabetic nephropathy. J Biol Chem. 2016;291:5688-5707.

17. Zakerkish M, Jenabi M, Zaeemzadeh N, Hemmati AA, Neisi N. the effect of iranian propolis on glucose metabolism, lipid profile, insulin resistance, renal function and inflammatory biomarkers in patients with type 2 diabetes mellitus: a randomized double-blind clinical trial. Sci Rep. 2019;9:7289.

18. Samadi N, Mozaffari-Khosravi H, Rahmanian M, Askarishahi M. Effects of bee propolis supplementation on glycemic control, lipid profile and insulin resistance indices in patients with type 2 diabetes: a randomized, double-blind clinical trial. J Integr Med. 2017;15:124-134.

19. Zercher A, Schulman S, Boone J. Quantitative measurement of hemoglobin A1c on the DCA Vantage Point-of-Care Analyzer as a diagnostic test for diabetes: An internal validation study. Clin Chem Lab Med. 2014:1-8.

20. Vanlin A. Applicable To Detail. Gundersen. 2018:2-5. Available from: https://www.gundersenhealth.org/app/files/public/6478/Lab-PoliciesGlucose---Cobas-c-111-Lab-1587.pdf

21. Bowling JL, Katayev A. An evaluation of the Roche cobas c 111. Lab Med. 2010;41:398-402.

22. TechPubs. Ins - Insulin (ECLIA), \#12017547122. 2010;(Ldl). Available from: https://healthabc.nia.nih.gov/sites/default/files/insulin on roche. pdf

23. Borai A, Livingstone C, Kaddam I, Ferns G. Selection of the appropriate method for the assessment of insulin resistance. BMC Med Res Methodol. 2011;11:158.

24. Koya-Miyata S, Arai N, Mizote A, Taniguchi Y, Ushio S, Iwaki K, Fukuda S. Propolis prevents diet-induced hyperlipidemia and mitigates weight gain in diet-induced obesity in mice. Biol Pharm Bull. 2009;32:20222028.
25. Sakai T, Ohhata M, Fujii M, Oda S, Kusaka Y, Matsumoto M, Nakamoto A, Taki T, Nakamoto M, Shuto E. Brazilian green propolis promotes weight loss and reduces fat accumulation in C57BL/6 mice fed a high-fat diet. Biol Pharm Bull. 2017;40:391-395.

26. Matsui T, Ebuchi S, Fujise T, Abesundara KJ, Doi S, Yamada $H$, Matsumoto K. Strong antihyperglycemic effects of water-soluble fraction of Brazilian propolis and its bioactive constituent, 3,4,5-tri-Ocaffeoylquinic acid. Biol Pharm Bull. 2004;27:1797-1803.

27. Sameni HR, Ramhormozi P, Bandegi AR, Taherian AA, Mirmohammadkhani M, Safari M. Effects of ethanol extract of propolis on histopathological changes and anti-oxidant defense of kidney in a rat model for type 1 diabetes mellitus. J Diabetes Investig. 2016;7:506-513.

28. Al-Hariri M, Eldin TG, Abu-Hozaifa B, Elnour A. Glycemic control and anti-osteopathic effect of propolis in diabetic rats. Diabetes Metab Syndr Obes. 2011;4:377-384.

29. Li Y, Chen M, Xuan H, Hu F. Effects of encapsulated propolis on blood glycemic control, lipid metabolism, and insulin resistance in type 2 diabetes mellitus rats. Evid Based Complement Alternat Med. 2012;2012:981896.

30. Oladayo Ml. Nigerian propolis improves blood glucose, glycated hemoglobin A1c, very low-density lipoprotein, and high-density lipoprotein levels in rat models of diabetes. J Intercult Ethnopharmacol. 2016;5:233-238.

31. Zhang H, Wang G, Beta T, Dong J. Inhibitory properties of aqueous ethanol extracts of propolis on alpha-glucosidase. Evid Based Complement Alternat Med. 2015;2015:587383.

32. Rivera-Yañez N, Rodriguez-Canales M, Nieto-Yañez O, Jimenez-Estrada M, Ibarra-Barajas M, Canales-Martinez MM, Rodriguez-Monroy MA. Hypoglycaemic and antioxidant effects of propolis of chihuahua in a model of experimental diabetes. Evid Based Complement Alternat Med. 2018;2018:4360356.

33. Joshi SR, Parikh RM, Das AK. Insulin--history, biochemistry, physiology and pharmacology. J Assoc Physicians India. 2007;55(Suppl):19-25.

34. Sforcin JM, Bankova V. Propolis: is there a potential for the development of new drugs? J Ethnopharmacol. 2011;133:253-260.

35. Kitamura $H$, Naoe $Y$, Kimura S, Miyamoto T, Okamoto S, Toda C, Shimamoto $Y$, Iwanaga T, Miyoshi I. Beneficial effects of Brazilian propolis on type 2 diabetes in ob/ob mice: possible involvement of immune cells in mesenteric adipose tissue. Adipocyte. 2013;2:227-236.

36. Aoi W, Hosogi S, Niisato N, Yokoyama N, Hayata H, Miyazaki H, Kusuzaki K, Fukuda T, Fukui M, Nakamura N, Marunaka Y. Improvement of insulin resistance, blood pressure and interstitial $\mathrm{pH}$ in early developmental stage of insulin resistance in OLETF rats by intake of propolis extracts. Biochem Biophys Res Commun. 2013;432:650-653.

37. Jasprica I, Mornar A, Debeljak Z, Smolcić-Bubalo A, Medić-Sarić M, Mayer L, Romić Z, Bućan K, Balog T, Sobocanec S, Sverko V. In vivo study of propolis supplementation effects on antioxidative status and red blood cells. J Ethnopharmacol. 2007;110:548-554. 